УДК 664.696:658.628(477.74): 005.642 .4
Кордзая Натела Ревазівна к.т.н., доцент кафедри маркетингу, підприємництва і торгівлі

E-mail: natela_k@ukr.net Ковалів Інна Олександрівна аспірант кафедри товарознавства та митної справи E-mail: kovaliv-inna@ukr.net Одеська національна академія харчових технологій Україна, м. Одеса, вул. Канатна, 112, 65039

\title{
АНАЛІЗ РИНКУ БАТОНЧИКІВ ЗЕРНОВИХ М. ОДЕСА
}

Нові тенденції у культурі харчування та проблема дефіциту таких біологічно активних речовин як харчові волокна, вітаміни та мінеральні елементи, спонукають виробників харчових продуктів до розробки та впровадження у виробництво збагаченої продукції. Здебільшого, у якості натуральних інгредієнтів для збагачення використовують продукти переробки овочів, фруктів та ягід. Одним із видів подібної продукції $\epsilon$ зернові батончики. У роботі досліджено асортимент батончиків зернових, що реалізуються у роздрібній торговельній мережі м. Одеси. Вивчено структуру цього асортименту, а саме визначено цінові відмінності, відмінності у складі продукції, а також співвідношення продукції вітчизняного та імпортного виробництва. Також вивчено харчову та енергетичну цінність представлених у торгівельних мережах батончиків.

Ключові слова: батончики зернові, збагачення, асортимент, харчові нутрієнти, торговельні мережі.

Постановка проблеми та її зв'язок з важливими науковими та практичними завданнями. Підвищення культури харчування, а також зміна стилю та образу життя населення, як нашої країни, так й світу у цілому, зумовлює зростання попиту на харчові продукти оздоровчого призначення що здатні забезпечувати добову потребу організму людини в основних харчових нутрієнтах [1]. При цьому, вони повинні бути зручними у споживанні, транспортабельності та використанні.

Відомо, що сьогодні, однією з найбільш актуальних проблем не тільки в Україні, але й в інших країнах світу $\epsilon$ проблема дефіциту у сучасному харчуванні таких біологічно активних речовин, як харчові волокна, вітаміни та мінеральні елементи. Саме тому, ефективний механізмом корекції харчування людини вважається збагачення харчових продуктів біологічно активними речовинами. Тому розробка та впровадження у виробництво виробів з використанням продуктів переробки овочів, фруктів та ягід $\epsilon$ доволі актуальними [1].

Одним із видів, збагаченої харчовими нутрієнтами продукції, готової до швидкого вживання, а також зручної у споживанні та транспортуванні $\epsilon$ батончики зернові Батончики зернові - це нове покоління харчових продуктів, джерело харчових волокон, вітамінів та мінералів [2,3]. Ці продукти служать гарним та корисним сніданком чи «перекусом» та мають високу енергетичну цінність, позитивно впливають на організм людини, здатні зняти «тягу до солодкого». Крім того, батончики зернові нормалізують перистальтику кишечнику, діяльність всього шлунково-кишкового тракту, допомагають оновити обмінні процеси в організмі, позитивно впливають на процеси розщеплення жирів, що не тільки добре позначається на фігурі, але й зменшує рівень холестерину в крові $[4,5]$.

Аналіз останніх публікацій по проблемі. У іноземній літературі зустрічається велика кількість наукових досліджень присвячених розробці батончиків зернових. У своїх наукових роботах Brahim Bchir [6], M rcia Vizzotto [7], Sarita Verma [8], Ramandeep Kaur [9] та інші науковці досліджували можливість використання побічних продуктів переробки фруктів; 
використання національних фруктів; виробництво безглютенових батончиків та інші питання зі збагачення поживними речовинами та покращення споживних властивостей батончиків. А ось аналіз вітчизняних інформаційних джерел показав, що на сьогодні, майже відсутні дослідження щодо виробництва та споживнихвластивостей батончиків зернових та розширення їх асортименту. Одним з авторів, що останнім часом досліджував це питання $\epsilon$ C.А. БажайЖежерун [10]. Дослідження науковця направлені на встановлення можливості використання біоактивованого зерна пшениці як основного компоненту батончика зернового.

Крім того, у результаті літературного огляду, можна говорити про те, що більшість наукових досліджень, що стосуються розробки батончиків зернових, присвячені солодким батончикам, до складу яких входять в основному фрукти, ягоди, горіхи, насінням та продукти їх переробки. Саме тому, наукові дослідження, щодо інших шляхів розширення асортименту зернових батончиків $\epsilon$ доволі актуальними.

Формулювання цілей дослідження.

Метою статі $\epsilon$ дослідження вітчизняного ринку батончиків зернових на прикладі м. Одеси, аналіз стану та структури цього ринку, а також встановлення перспективи його подальшого розвитку.

Виклад основних результатів та їх обґрунтування. Сьогодні, на кафедрі товарознавства та митної справи Одеської національної академії харчових технологій проводиться робота з дослідження якості батончиків зернових, одним 3 етапів якої $\epsilon$ аналіз асортименту даної продукції представленої у роздрібній торговельній мережі м. Одеси.

Аналіз асортименту батончиків зернових, що реалізується в роздрібній торговельній мережі м. Одеси проводиться за допомогою загальнонаукових методів науковогодослідження, а саме:спостереження, аналізу, синтезу.

Дослідження проводилися у таких великих мережах супермаркетів м. Одеси як «АТБ», «Копійка», «Сільпо», «Таврія В» та «Обжора». Вибір саме цих супермаркетів можна пояснити тим, що їх магазини знаходяться у кожному районі м. Одеси, а це дасть змогу більш об'єктивно вивчити асортимент зернових батончиків та їх здатність задовольняти попит споживачів даної продукції. Результати дослідження наведено у табл. 1.

Дослідження показали, що асортимент батончиків зернових за останні два роки значно змінився: якщо раніше на споживчому ринку цей вид продукції був представлений здебільшого імпортними продуктами (до 5 торгових марок) та у меншій мірі вітчизняною - (1-2 торгові марки), то на даний час український виробник представлений вже 4 торговими марками, та складає непогану конкуренцію зарубіжній продукції. Тобто, спостерігається зростання даного сегменту ринку товарів вітчизняного походження, що зумовлює доцільність наукових розробок нових видів батончиків зернових.

Крім того, варто відзначити, що батончики зернові вітчизняного виробництва реалізуються за більш доступними цінами: їх вартість складає до 6,00 грн, тоді як імпортні батончики коштують у діапазоні 5,20 ... 14,99 грн за штуку. Результати аналізу маркування на предмет дослідження харчовоїта енергетичної цінності батончиків наведено на рис. 2 та рис.3.

У результаті аналізу, можна говорити про те, що харчова цінність батончиків зернових різних виробників знаходиться майже на одному рівні. Кількість білків змінюється від 4,0 до 6,7 г на 100 г продукту; жири від 6,7 до 16 г на 100 г продукту та вуглеводи - від 55,0 до 71,5 г на 100 г продукту. Кількість жирів та вуглеводів значно варіюється залежно від кількості інгредієнтів таких як: рослинні жири, патока, мальтодекстрин, інверсний сироп, глюкозно-фруктозний сироп, мед.

Енергетична цінність батончиків зернових $\epsilon$ достатньо високою. Найнижчу енергетичну цінність мають батончики ТМ «VitaFruit» та TM «Fitto light» 341 ккал/1428 кДж на 100 г продукту, а найвищу - батончики ТМ «Corny» та TM «Ва!» 445 ккал/1870 кДж та 432 ккал/1817 кДж на 100 г продукту відповідно.

Також, під час дослідження було встановлено, що вітчизняні батончики зернові випускаються 3 меншою різноманітністю смаків у порівнянні з імпортними аналогами. 
Таблиця 1

Аналіз асортименту батончиків зернових у торгівельній мережі м. Одеси

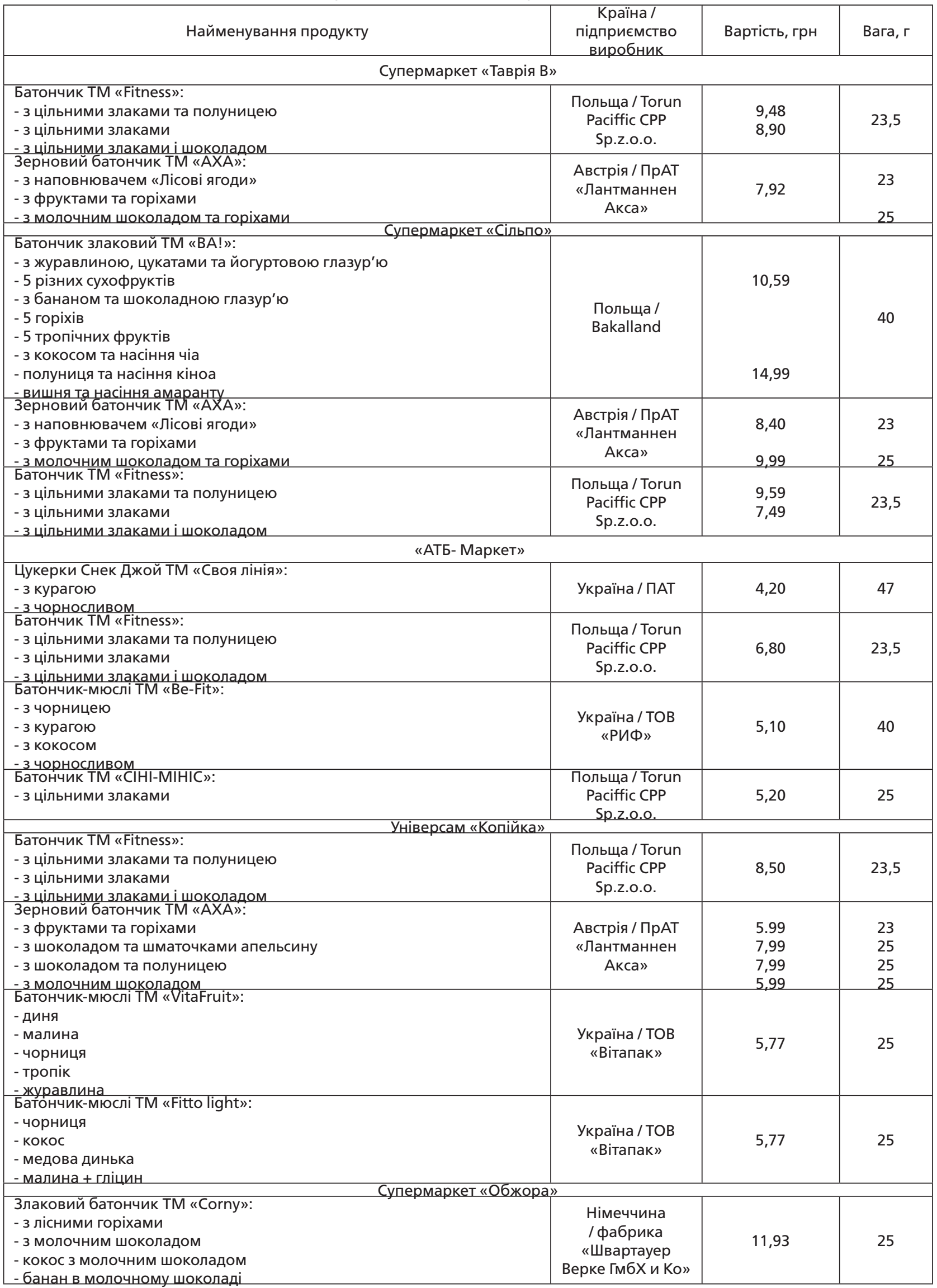




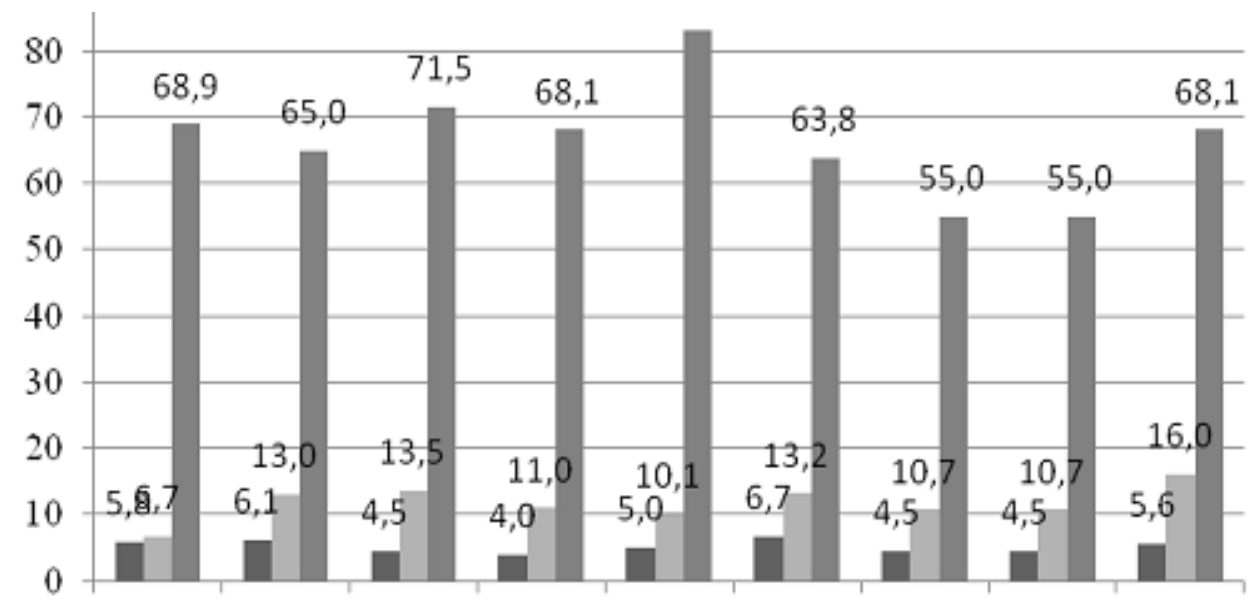

пБілкн, г на 100 г Пини, г на 100 г шВугеводи, г на 100 г

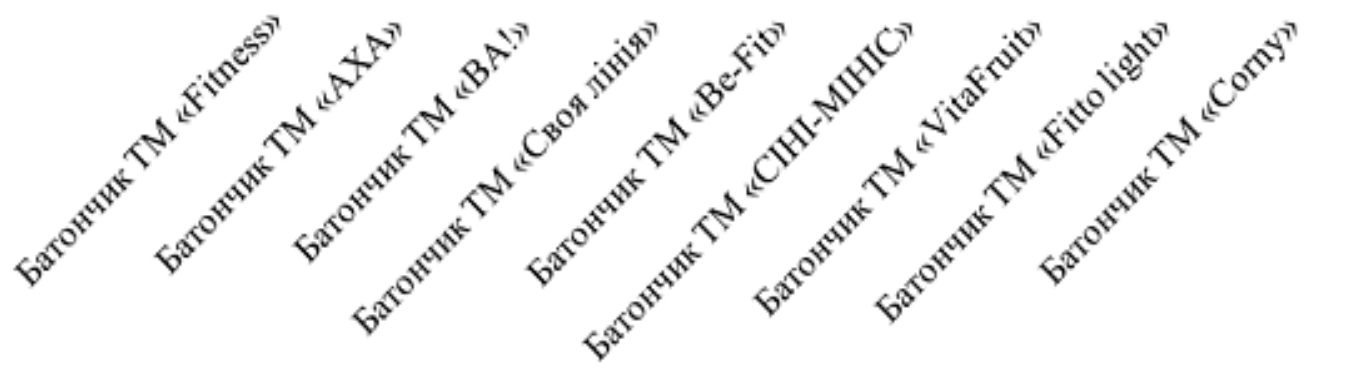

Рис. 2 - Харчова цінність батончиків зернових на 100 г продукту (зазначено на пакуванні)

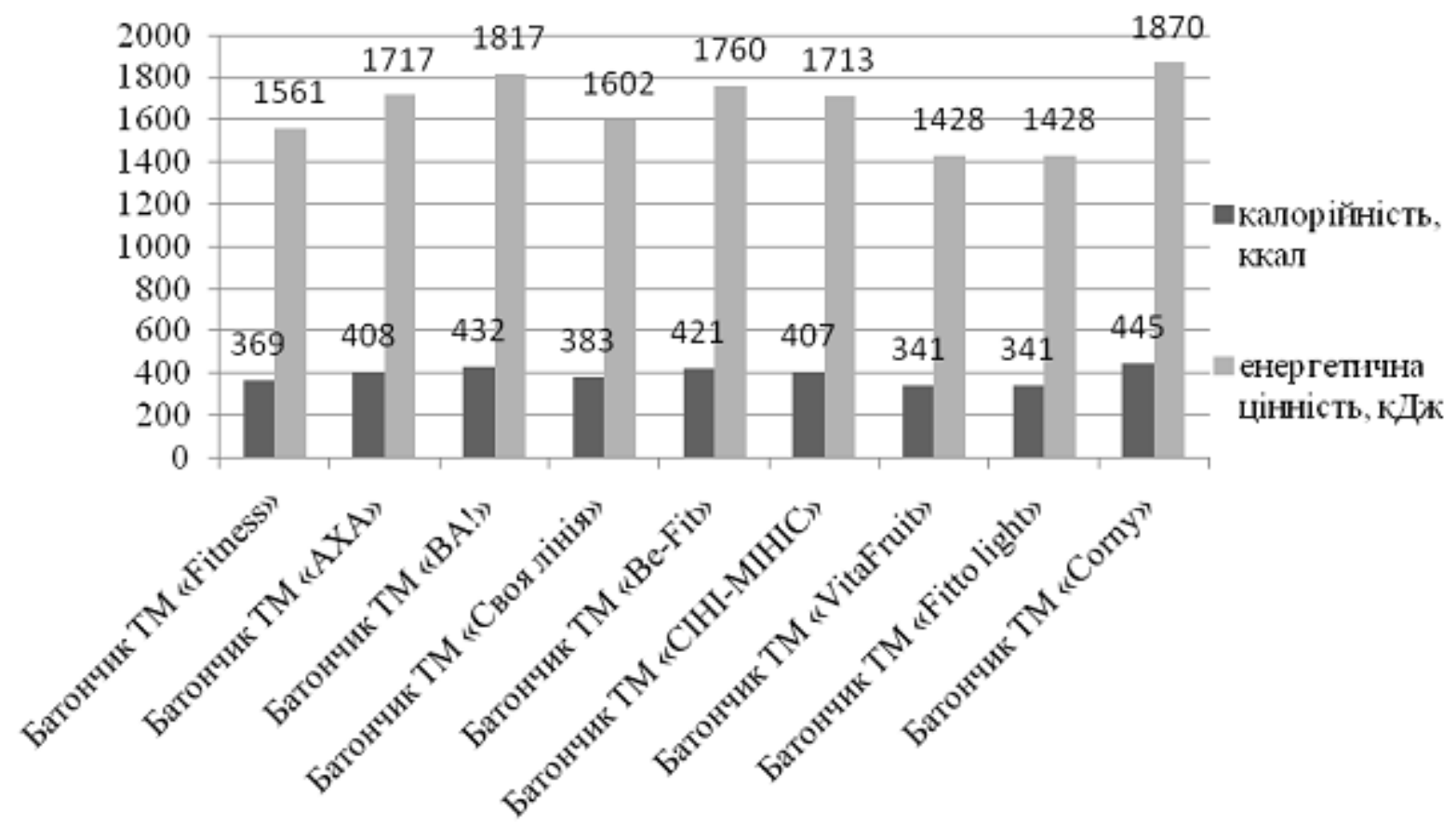

Рис. 3 - Енергетична цінність батончиків зернових на 100 г продукту (зазначено на пакуванні) 


\begin{abstract}
Висновки та перспективи подальших досліджень. Проведений аналіз показав асортименту батончиків зернових, представлених у торгівельній мережі м. Одеси показав, що український ринок батончиків зернових стрімко зростає, вітчизняний виробник, за останні два роки, збільшив кількість видів продукції, що реалізуються в роздрібній торговельній. Варто також відзначити, що вартість українського зернового батончика $\epsilon$ набагато нижчою за вартість імпортного.

Отже, отримані результати вказують на те, що, на сьогодні, збагачення таких харчових продуктів як батончики зернові добавками рослинного походження (коренеплодами селери та моркви та спеціями) $\epsilon$ досить актуальним. Виробництво подібної продукції дозволить використовувати ї̈ для корекції щоденних раціонів харчування населення.
\end{abstract}

\section{Література:}

1. Стеценко Н. О., Андрейченко Н. О. Розроблення способу виробництва фруктовогоріхових батончиків для спецконтингентів. Оздоровчі харчові продукти та дієтичні добавки: технології, якість та безпека : зб. матеріалів міжнар. наук.-практ. конф., 12-13 трав. 2016 р. Київ : НУХТ, 2016. С. 12 - 14.

2. Зубар Н.М., Руль Ю.В., Булгакова М.К. Фізиологія харчування: практикум: навч. посіб. Київ: «Центр учбової літератури», 2013. $208 \mathrm{c}$.

3. Sharma $C$ et al. Cereal bars - A healthful choice a review. Carpathian Journal of Food Science and Technology. 2014. Vol. 6 (2). P. 29 36.

4. Aleksejeva S., Siksna I., Rinkule S. Composition of Cereal Bars. Journal of Health Science. 2017. Vol. 5. P. $139-145$.

5. Palazzolo G. Cereal bars: they're not just for breakfast anymore. Cereal Foods World. 2003. Vol. 48. (2). P. 70.

6. Bchir B. et al. Effect of pear apple and date fibres incorporation on the physicochemical, sensory, nutritional characteristics and the acceptability of cereal bars. Food Science and Technology International. 2017. Vol. 24. No. 3. P. $198-2008$.

7. Fernanda I. G. R. et al. Manufacturing and Sensorial Acceptance of Cereal Bars Enriched with Flaxseed (Linum usitatissimum) Flour. Journal of Food Research. 2018. Vol. 8. No. 1.

8. Verma S., Khetrapaul N., Verma V. Development and Standardisation of Protein Rich Sorghum Based Cereal Bars. Int. J. Curr. Microbiol. App. Sci. 2018. Vol. 7. No. 5. P. $2842-2849$.

9. Kaur R. et al. Development of glutenfree cereal bar for gluten intolerant population by using quinoa as major ingredient. Journal of food science and technology. 2018. Vol. 55. No. 9. P. $3584-3591$.

10. Бажай-Жежерун С. А. Батончик глазурований на основі пророщеного зерна пшениці. Наук. пр. НУХТ. 2014. Вип. 20. Т. 3. С. $189-196$.

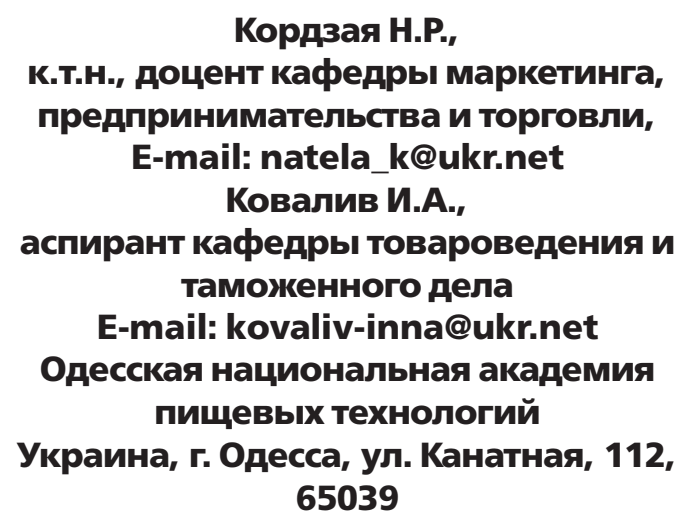

Кордзая H.P.,

к.т.н., доцент кафедры маркетинга, предпринимательства и торговли, E-mail: natela_k@ukr.net Ковалив И.А., аспирант кафедры товароведения и таможенного дела

E-mail: kovaliv-inna@ukr.net

Одесская национальная академия пищевых технологий

Украина, г. Одесса, ул. Канатная, 112, 65039

\section{АНАЛИЗ РЫНКА БАТОНЧИКОВ ЗЕРНОВЫХ Г. ОДЕССА}

Сегодня, новые тенденции в культуре питания и проблема дефицита таких биологически активных веществ как пищевые волокна, витамины и минеральные элементы, побуждают производителей пищевых продуктов к разработке и внедрению в производство обогащенной продукции. В основном, в качестве натуральных ингредиентов, для обогащения используют продукты переработки овощей, фруктов и ягод. Одним из видов подобной продукции являются зерновые батончики. Батончики зерновые - это новое поколение продуктов питания, источник пищевых волокон, витаминов и минералов, удобный формат готового продукта с идеальным составом. Эти продукты служат хорошим и полезным завтраком или «перекусом» и имеют высокую энергетическую ценность, положительно влияют на 
организм человека, способны снять «тягу к сладкому». Кроме того, батончики зерновые нормализуют перистальтику кишечника, деятельность всего желудочно-кишечного тракта, помогают обновить обменные процессы в организме, положительно влияют на процессы расщепления жиров, что не только хорошо сказывается на фигуре, но и уменьшает уровень холестерина в крови, повышая продолжительность и качество жизни человека.

В работе исследован ассортимент батончиков зерновых, реализуемый в розничной торговой сети г. Одессы. С целью комплексного анализа всех характеристик ассортимента, перечень продаваемой продукции представлен в виде таблицы с указанием наименования, стоимости и производителя батончиков зерновых по каждой торговой сети отдельно. Получены данные, по росту данного сегмента рынка за счет расширения ассортимента батончиков отечественного производства. Проанализирована ценовая политика производителей батончиков зерновых. Изучено пищевую и энергетическую ценность батончиков зерновых, а также определено соотношение продукции отечественного и импортного производства на современном рынке Украины (базируясь на анализе ассортимент нескольких торговых сетей). Полученные результаты подтверждают перспективность разработки и вывода на рынок новых батончиков зерновых обогащенных добавками растительного происхождения (корнеплодами сельдерея и моркови, специями). Производство подобной продукции позволит использовать ее для коррекции как обычных (ежедневных) рационов питания населения, так и рационов людей с особыми пищевыми потребностями.

Ключевые слова: батончики зерновые, обогащение, ассортимент, пищевые нутриенты, торговые сети.

\author{
Natela Kordzaia, \\ Ph.D. in Technical Sciences, Associate \\ Professor \\ Department of Marketing, Business and \\ Trade \\ E-mail: natela_k@ukr.net \\ Inna Kovaliv, \\ post-graduate student Department of \\ commodity and customs \\ E-mail: kovaliv-inna@ukr.net \\ Odessa National Academy of Food \\ Technologies \\ Ukraine, Odessa, street. Kanatna, 112, \\ 65039
}

\section{MARKET ANALYSIS OF CEREAL BARS IN ODESA CITY}

Nowadays there are a lot of new trends in nutrition culture and the there is a problem of lack of such biologically active substances as edible fibers, vitamins and minerals. And all this can prompt food manufacturers to the new enriched products development, production and market introduction. Mostly, as a natural ingredient for product enrichment manufacturers use products of vegetables, fruits and berries processing. One of such products are cereal bars. Cereal bars are a new generation of food products, a source of nutritious fibers, vitamins and minerals, and a convenient, ready-made product with perfect composition.

These products serve as a good and useful breakfast or "snack» and have high energy value, have a positive effect on the human body, which can remove "craving for sweet.»

In addition, cereal bars can normalize intestine peristalsis, activate entire gastrointestinal tract, can help to update metabolic processes in the body, have a positive effect on fission processing, which not only affects the body, but also reduces blood cholesterol level, increasing the duration and quality of human life.

The trade network assortment of grain bars in Odessa is studied. The assortment list is presented in the form of a table indicating the name, cost and manufacturer of cereal bars for each trade network separately for the purpose of comprehensive analysis of all characteristics. The data concerning the growth of this market, due to expanding the range of domestic production bars 
it explored in this article.

The price policy of cereal bars producers is analyzed. The nutritional and energy values of cereal bars are studied, as well as the ratio of domestic and imported production in the modern market of Ukraine (based on an analysis of the range of several retail chains). The obtained results confirm prospect of development and introduction on the market of new cereals bars kinds enriched with additives of plant origin (root crops of celery and carrots, spices). The production of such products will allow them to be used for the correction of both normal (daily) diets of the population and the diets of people with special nutritional needs.

Key words: cereal bars, enrichment, assortment, nutritional elements, trade networks.

\section{References:}

1. Stetsenko N.O., Andreychenko N.O. (2016). Rozroblennya sposobu virobnitstva fruktovo-horikhovikh batonchikiv dlya spetskontinhentiv. Ozdorovchi kharchovi produkti ta diyetichni dobavki: tekhnolohiyi, yakist' ta bezpeka [Development of the method of production of fruit nuts for special confectioners. Healthy foods and dietary supplements: technology, quality and safety]. Zbirnik materialiv mizhnarodnoyi naukovopraktichnoyi konferentsiyi NUHT (pp. 12-14). Kiev [in Ukrainian].

2. Zubar N.M., Rul' U.V., Bulhakova M.K. (2013). Fiziolohiya kharchuvannya: praktikum [Physiology of nutrition: a workshop]. Kiyiv : «TSentr uchbovoyi literaturi» [in Ukrainian].

3. Sharma C et al. (2014). Cereal bars - A healthful choice a review. Carpathian Journal of Food Science and Technology. Vol. 6 (2). P. $29-36$ [in English].

4. Aleksejeva S., Siksna I., Rinkule S. (2017). Composition of Cereal Bars. Journal of Health Science. Vol. 5. P. 139 - 145 [in English].

5. Palazzolo G. (2003). Cereal bars: they're not just for breakfast anymore. Cereal Foods World. Vol. 48. (2). P. 70 [in English].

6. Bchir B. et al. (2017). Effect of pear apple and date fibres incorporation on the physicochemical, sensory, nutritional characteristics and the acceptability of cereal bars. Food Science and Technology International. Vol. 24. No. 3. P. $198-$ 2008 [in English].
7. Fernanda I. G. R. et al. (2018). Manufacturing and Sensorial Acceptance of Cereal Bars Enriched with Flaxseed (Linum usitatissimum) Flour. Journal of Food Research. Vol. 8. No. 1 [in English].

8. Verma S., Khetrapaul N., Verma V. (2018). Development and Standardisation of Protein Rich Sorghum Based Cereal Bars. Int. J. Curr. Microbiol. App. Sci. Vol. 7. No. 5. P. $2842-$ 2849 [in English].

9. Kaur R. et al. (2018). Development of gluten-free cereal bar for gluten intolerant population by using quinoa as major ingredient. Journal of food science and technology. Vol. 55. No. 9. P. 3584 - 3591 [in English].

10. Bazhay-Zhezherun S.A. (2014). Batonchik hlazurovaniy na osnovi proroshchenoho zerna pshenitsi [Glazed bar on germinated wheat grain]. Nauk. pr. NUHT Scientific works of the National University of Food Technologies, 3, Vol. 20. 189 - 196 [in Ukrainian]. 